\title{
Penerapan Azas Iktikad Baik dalam Proses Jual Beli Ikan Hasil Tangkapan di Pelabuhan Perikanan Kota Probolinggo
}

\author{
Budi Hariyanto \\ Universitas Panca Marga, Probolinggo \\ budi.hariyanto@upm.ac.id \\ Edy Sumarno \\ Universitas Panca Marga, Probolinggo \\ edysumarno1963@gmail.com
}

\begin{abstract}
Freedom of contract, which is an indicator of an agreement or contract. Thus, it is hoped that a fair and balanced agreement will emerge and be implemented based on principles of good faith for the parties and lawful reasons. However, practically there are still many standard contract models (standard contracts) which tend to be considered one-sided, unbalanced and unfair. The implementation of an agreement can be applied in various fields or activities, for example the field of buying and selling carried out by fishermen is the catch that is brought closer to the fish auction port as is carried out in direct negotiations as is the case in buying and selling activities in traditional markets based on customary law, where buyers / wholesalers in the form of wholesalers are waiting at the port side to negotiate. Because in the fish trading activities carried out between fishermen and collectors / wholesalers are not carried out in writing and in a structured manner so that they are prone to causing conflicts between them, because this activity is carried out according to customary law. This is like the activities in traditional markets, even though these activities are carried out at fish auction ports which are facilitated by the government, so that in order to avoid conflicts, the implementation of buying and selling activities can be carried out in writing which requires government intervention through related agencies and the application of good faith principles in the sale and purchase of fish at the Mayangan Fishing Port, Probolinggo City.
\end{abstract}

Keywords: Good Faith, Avoiding Conflict, Fishing Port.

\begin{abstract}
Abstrak
Dalam dunia perdagangan masing-masing pihak umumnya menggunakan perjanjian, apakah bentuknya tertulis maupun menurut hukum kebiasaan, yang mana dalam hukum perjanjian dikenal dengan istilah azas kebebasan berkontrak walaupun dalam pelaksanaanya masih ada yang menggunakan bentuk standard kontrack. Di sini para pihak yang terlibat dalam pelaksanaan jual beli bebas menentukan objek yang diperjanjikan, sehingga mereka memiliki posisi yang sejajar. Maka dari itu dimungkinkan untuk diperoleh suatu kegiatan bisnis yang berdasarkan keadilan dan terjadi keseimbangan antara mereka. Selain itu setiap orang yang melaksanakan kegiatan bisnis wajib menerapkan azas iktikad baik bagi para pihak serta sebab yang halal. Implementasi kontrak dapat diterapkan pada berbagai bidang atau suatu kegiatan misalnya bidang jual beli yang dilakukan oleh nelayan merupakan hasil tangkapannya yang di bawa merapat ke pelabuhan pelelangan ikan, karena di pelabuhan pelelangan ikan sebagaimana yang dilakukan negoisasi secara langsung sebagaimana halnya dalam kegiatan jual beli di pasar tradisional berdarkan
\end{abstract}


hukum kebiasaan, di mana para pembeli/pedagang secara grosir yang bentuknya perkulakan sudah menunggu di pinggir pelabuhan untuk melakukan negoisasi. Karena di dalam kegiatan jual beli ikan yang dilakukan antara nelayan dengan pengepul/grosir tidak dilakukan secara tertulis dan tersetruktur sehingga rawan menimbulkan konflik di antara mereka, karena kegiatan ini dilakukan menurut hukum kebiasaan. Hal ini tidak ubahnya sebagaimana kegiatan yang dilakukan di pasar-pasar tradisional, padahal kegiatan tersebut dilakukan di pelabuhan pelelangan ikan yang difasilitasi oleh pemerintah, sehingga dalam rangka untuk menghindari konflik dalam pelaksanaan kegiatan jual beli bisa dilakukan secara tertulis yang mana perlu adanya campur tangan pemerintah melalui dinas terkait dan penerapan azas iktikad baik pada pelaksanaan jual beli ikan di Pelabuhan Perikanan Mayangan Kota Probolinggo.

Kata Kunci : Kebebasan Berkontrak, Menghindari Konflik, Pelabuhan Perikanan

\section{A. PENDAHULUAN}

Perjanjian merupakan bagian yang terpenting di dalam kehidupan manusia terutama di dalam melaksanakan kegiatan perdangan. Para pihak untuk melaksanakan kegiatantersebut agar tidak terjadi kesalah pahaman bahkan mengarah kepada konflik di antara mereka yang terlibat biasanya dituangkan pada bentuk kesepakatan. Kesepakatan di dalam kegiatan perdagangan biasanya dituangkan dalam bentuk naskah perjanjian, begitu pula perjanjian yang dibuat secara otentik artinya suatu akta yang dibuat oleh pejabat yang berwenang, maupun suatu perjanjian dibuat secara di bawah tangan yang dibuat antara para pihak yang melakukan suatu kesepakatan. Pada dasarnya hukum kontrak dimaksudkan sebagai hukum yang mengatur tentang perjanjian dalam dunia bisnis sehingga suatu perjanjian merupakan suatu tindakan yang dilakukan para pihak untuk mana satu pihak atau lebih melakukan perikatan bagi diri sendiri untuk pihak yang lainnya. Seperti yang telah dituangkan secara khusus pada Buku yang ke III perihal perikatan dalam Pasal 1233 KUH Perdata sampai dengan Pasal 1864 KUH Perdata.

Pada umumnya sebelum melakukan perjanjian para pihak senantiasa mengawali dengan proses negosiasi, dengan melaksanakan negosiasi terlebih dahulu masing-masing pihak akan menemukan bentuk kesepakatan seperti apa yang akan mereka inginkan nantinya akan mereka sepakati dalam bentuk perjanjian, karena para pihak memiliki kepentingan yang berbeda dalam melaksanakan tawar menawar dalam kegiatan jual-beli. Karena setiap orang secara kodrat memiliki hak untuk mendapatkan pelayanan diatas apapun dalam tingkatan haknya sebagai manusia. Dengan mendapatkan perlindungan secara individu, maka setiap manusia akan memiliki 
kebebasan dan dilindungi hak-haknya untuk melaksanakan setiap aktifitasnya. Hak-hak tersebut pada hakikatnya bertujuan untuk melindungi kehidupan pribadi manusia atau kedualatan individu atas dirinya sendiri maupun pihak lainnya.

Didasari dengan adanya pelaksanaan kontrak diharapkan perbedaan persepsi pada pelaksanaan jual beli dapat terakomodir yang karena telah diatur dengan peraturan perundang-undangan yang yang mereka buat sendiri. Seperti penerapan Azas Pacta Sunt Servanda yang lazim di temui dalam hukum perjanjian, yang menyatakan bahwa masing-masing pihak yang telah menyepakati perjanjian berlaku sebagaimana Undang-Undang, dalam hal ini mengandung arti bahwa mereka yang terlibat dalam perjanjian jual beli sudah terikat dengan kesepakatan yang sudah mereka buat. Sebagaimana dalam perjanjian jual beli ikan di Tempat Pelelangan Ikan (TPI) Mayangan Probolinggo yang sering terjadi perbedaan pendapat karena dilakukan menurut hukum kebiasaan akan teratasi dengan perlakuan iktikad baik antar sesama orang-orang yang terlibat.apabila hal ini akan mudah tercapai dengan adanya campur tangan pemerintah, karena dilakukan lewat hubungan kekeluargaan antara masyarakat yang terlibat dengan pemerintah setempat sehingga akan terjadi posisi keseimbangan dan keadilan yang terjadi untuk membantu individu atau masyarakat dalam rangka memenuhi kebutuhan dasarnya. ${ }^{1}$

Iktikad baik dalam pelaksanaan perjanjian merupakan suatu barometer dalam pelaksanaan dunia bisnis, sehingga dengan penerapan azas iktikad baik akan terhindar dari konflik dan perbedaan pendapat diantara pihak-pihak yang melakukan jual beli. Walaupun dalam hukum perjanjian dikenal pula yang namanya azas kebebasan berkontrak, hal ini dikonotasikan bahwa setiap orang bebas mengadakan perjanjian dengan siapapun, dimanapun dan menentukan sendiri objek perjanjiannya. Walaupun demikian dalam implementasi di lapangan masih ada dijumpai cara-cara bentuk perjanjian baku yang menyimpang dari rasa keadilan kerena mengarah kepada perjanjian yang berat sebelah, karena hanya memihak kepada pihak yang kuat, tidak adil, tidak memberikan keseimbangan dan berat sebelah, karena penerapan azas kebasan berkontrak merupakan suatu azas yang karakteristiknya hanya memihak

\footnotetext{
${ }^{1}$ Edi Suharto, Analisa Kebijakan Publik, Alfabeta, Bandung, 2010, 34.
} 
kepada satu individu atau satu pihak saja dalam pelaksanaan kehidupan pribadi maupun dalam kehidupan pranata sosial. ${ }^{2}$

Implementasi perjanjian dapat diterapkan dalam berbagai bidang atau suatu kegiatan misalnya bidang jual beli yang dilakukan oleh nelayan yang hasil tangkapannya di bawa merapat ke pelabuhan pelelangan ikan, karena di pelabuhan pelelangan ikan sebagaimana yang dilakukan negoisasi secara langsung sebagaimana halnya dalam kegiatan jual beli di pasar tradisional berdarkan hukum kebiasaan, di mana para pembeli secara grosir yang bentuknya perkulakan sudah menunggu di pinggir pelabuhan untuk melakukan negoisasi.

Sebagaimana yang diatur dalam Perda Kota Probolinggo Nomor 9 Tahun 2011 yang disebut dengan pasar tradisional yaitu pasar yang diadakan serta dikelola oleh Pemerintah Daerah, atas swadaya masyarakat, swasta, BUMN dan BUMD termasuk pula kegiatannya bekerjasama antara swasta yang tempat kegiatan berupa toko, bedakbedak atau berbentuk outlet-outlet dihuni dan dikelola oleh prdagang yang bersekala kecil, menengah serta pengelola koperasi dengan pelaksanaan negoisasi jual beli barang yang diperdagangkan secara tradisional atau kebiasaan. Termasuk pula pelaksanaan jual beli ikan di Tempat Pelelangan Ikan Mayangan dilaksanakan berdasarkan hukum kebiasaan yang dilaksanakan secara tradional.

Pasar merupakan suatu tempat kegiatan bisnis mempunyai berbagai bentuk yang selama ini cenderung ditunjukkan dalam prinsip konseptualnya dalam substansi keberadannya sebagaimana halnya sebuah institusi yang dikelola dengan pranata sosial. Secara perencanaan, sistem yang ada pada keberadaan pasar merujuk kepada pelaksanaan hubungan antara penjual dan pembeli dalam hal ini hubungan penawaran dan permintaan yang mana menuju kepada nilai tambah yang sangat kompleks. Istilah ini dalam dunia pasar sering digunakan dalam sebutan mekanisme pasar terkendali, karena penentuan harga tidak saja ditentukan oleh masyarakat dalam hal ini pelaku usaha, tetapi peran serta pemerintah juga diharapkan dalam rangka pengendalian harga-harga agar masyarakat tidak seenaknya menentukan harga dipasar, sehingga dapat tercapai kesejahteraan masyarakat (Undang-Undang Nomor 25 Tahun 2007).

${ }^{2}$ Priyono, Agus, Aspek Keadilan Dalam Kontrak Bisnis, Jurnal Ilmiah Law Reform, Volume 14 Nomor 1, Tahun 2018, 20. 
Pasar juga diasumsikan sebagai institusi yang merupakan beberapa bangunan sosial dari sekelompok masyarakat yang mana mengakomodir beberapa variabel pada penawaran dan permintaan yang disepakati sendiri sebagaimana ideologi, kebijakan politik, kebiasaan dan adat istiadat, nilai-nilai keagamaan dan yang lainnya. (Hamzah, 2011 : 219). Demikian pula jatuh bangunnya sebuah pasar sebagai institusi dalam suatu negara merupakan jalan pembuka bagi kekuatan maupun suatu kelemahan pada negara itu sendiri. $^{3}$

Sedangkan keberadaan pasar modern tentunya lain dengan pasar yang berbentuk tradisional, karena dalam praktik pasar moderen antara konsumen dengan penjual tidak melakukan komunikasi secara langsung. Konsumen dapat memperoleh harga pada daftar harga yang sudah tertera pada barang yang dijual dan diberi kode (bercode) terdapat pada suatu bangunan serta pelayanannya dilakukan sendiri oleh konsumen tanpa dilayani oleh pramuniaga disebut juga dengan swalayan. Umumnya barang-barang yang ditawarkan bukan saja barang-barang yang tahan lama seperti kosmetik, tetapi swalan, minimarket, hipermarket, maupun supermarket yang juga menawarkan berbagai macam barang-barang kebutuhan sehari-hari untuk dapur seperti bahan-bahan makanan, buah-buahan, daging segar, sayur mayur, ikan segar dan lainlain sebagainya, serta pada umumnya barang lainnya yang dijual yaitu barang yang bertahan lama

Menurut Adam Smith yang dikutip Bambang Sugiharto : Dalam konsep ekonomi pasar atau pasar bebas, bukan saja mekanisme pasar yang berlaku tetapi mekanisme pasar terkendali juga diterapkan artinya intervensi pemerintah justru dibutuhkan dalam rangka menghindari masalah kesenjangan itu, dalam hal ini pemerintah bertugas :

a. Mempertahankan supaya tidak ada kegiatan dari individu-individu maupun kelompok perbuatan yang mengarah pada tindakan secara sewenang-wenang maupun pemaksaan kehendak yang dapat merugikan pihak lain.

b. Penegakan hukum dalam rangka menuju masyarakat yang sejahtera ;

c. Membangun dan melaksanakan pemerintah dan negara yang baik, berwibawa serta bertanggung jawab.

Sehingga intervensi pemerintah merupakan pedoman dalam rangka pengambilan keputusan politik perekonomian negara kita dan hukum perekonomian

\footnotetext{
${ }^{3}$ Fahri Hamzah, Negara Pasar Dan Rakyat. Yayasan Faham Indonesia, Jakarta, 2011, 241.
} 
pemerintah dan diperlukan sejauh itu menunjang kebebasan dan keadilan. Penjabaran dari peran pemerintah dan kebebasan pasar ini setiap negara mempunyai perbedaan dan kebijakan masing-masing.

Sedangkan dengan kemunculan pasar modern akhir-akhir ini merupakan tuntutan dan konsekuensi dari gaya hidup yang berkembang pada masyarakat modern, hal ini bukan saja kehidupan yang ada di kota besar tapi sudah berkembang pada kota kecil yang ada negara ini, sangatlah gampang dijumpai di lingkungan terdekat kita, seperti hipermaket, super market, dan minimarket. Keberadaan pasar moderen yang disebutkan di atas, sangatlah diminati oleh masyarakat sebagai konsumennya, dengan alasan mereka sudah tidak perlu melakukan negosiasi harga lagi dan bisa terlayani dengan cepat karena barang yang diharapkan bisa mereka pilih sendiri. Di samping itu masyarakat yang berbelanja di pasar moderen dapat menikmati suasana yang nyaman, yang bertolak belakang dengan keberadaan pasar tradisional.

Minimarket-minimarket yang ada di Kota Probolinggo saling bersaing untuk menyuguhkan pelayanan yang terbaik bagi konsumennya dengan melengkapi produk yang diperdagangkan, menjamin mutu produk yang dijual, kelengkapan produk yang ditawarkan, maupun cara promosi yang dilakukan oleh pengelola minimarket yang terkesan modern dengan sarana yang lebih moderen, agar masyarakat/konsumen dapat tertarik dengan produk dan harga yang ditawarkan. Kondisi inilah yang membuat masyarakat akan beralih dari pasar tradisional ke pasar modern, demikian juga pada pelaksanaan jual beli ikan di pelabuhan perikanan mayangan Kota Probolinggo yang semula menggunakan cara yang tradisional lambat laun akan beralih dengan melaksanakan jual beli ikan menggunakan cara yang lebih modern, yaitu dengan menggunakan sistem pelelangan yang difasilitasi oleh Unit Pelaksana Teknis Tempat Pelelangan Ikan (UPTTPI) sehingga konflik antara mereka akan terhindar.

Metode yang diperguanakan dalam penelitian ini adalah metode empiris. Penelitian empiris adalah merupakan salah satu cara melakukan pencarian data dengan cara memperolehnya di lokasi secara langsung pada sumber yang ada di lapangan dan melakukan investigasi antara peneliti dengan sumber informasi. ${ }^{4}$ Jadi penelitian empiris merupakan penelitian yang metode pengumpulan datanya menggunakan

\footnotetext{
${ }^{4}$ Muhammad Idrus,, Metode Penelitian Ilmu Soial, Erlangga, Jakarta, 2009, 84.
} 
metode yang langsung diperoleh dilapangan dan berhadapan langsung dengan fenomena-fenomena yang ada di lapangan. Pada proses penelitian dengan metode empiris, dalam proses penelitian di lapangan sering pula menggunakan data kualitatif sebagai upaya penyederhanaan.

Lebih lanjut pada metode kualitatif, teknik pencarian datanya dilaksanakan berdasarkan keadaan yang alamiah (natural setting) sehingga ini yang menjadi sumber data yang utama, serta untuk cara pengumpulan datanya dilakukan dengan cara penelitian lapangan/observasi di lapangan (participan observation) serta wawancara yang mendalam serta menggunakan metode dokumentasi (in dept interview). ${ }^{5}$

Sedangkan dalam penelitian ini mencoba untuk menjawab apa saja faktor-faktor yang menyebabkan pelaksanaan jual beli ikan hasil tangkapan nelayan sering terjadi konflik antara para pihak di pelabuhan pelelangan ikan Kota Probolinggo dan untuk memperoleh data tentang cara apa yang akan dilaksanakan oleh dinas terkait dalam upaya menghindari konflik dalam praktek jual beli ikan hasil tangkapan nelayan di pelabuhan pelelangan ikan Mayangan Kota Probolinggo.. Hal ini dikarenakan merupakan penelitian yang sosiolegal yaitu menempatkan hukum pada gejala sosial memfokuskan kepada gejala-gejala individu atau masyarakat. ${ }^{6}$

\section{B. HASIL DAN PEMBAHASAN}

\section{Faktor-Faktor yang Menyebabkan Pelaksanaan Jual Beli Ikan Sering Terjadi Konflik Antar Para Pihak}

Implementasi perjanjian dapat diterapkan dalam berbagai bidang atau suatu kegiatan misalnya bidang jual beli yang dilakukan oleh nelayan yang hasil tangkapannya di bawa merapat ke pelabuhan pelelangan ikan, karena di pelabuhan pelelangan ikan sebagaimana yang dilakukan negoisasi secara langsung sebagaimana halnya dalam kegiatan jual beli di pasar tradisional berdarkan hukum kebiasaan, di mana para pembeli secara grosir yang bentuknya perkulakan sudah menunggu di pinggir pelabuhan untuk melakukan negoisasi.

Dalam pelaksanaan perjanjian jual beli ikan hasil tangkapan di Pelabuhan Perikanan Mayangan Kota Probolinggo sebelum adanya pembinaan dari dinas terkait sering terjadi konflik antara pemilik kapal (juragan), nelayan dan pedagang

\footnotetext{
${ }^{5}$ Sugiyono, Memahami Penelitian Kualitatif, CV. Alfabeta, Bandung, 2014, 84.

${ }^{6}$ Peter Mahmud, Penelitiah Hukum, Prenada Media, Jakarta, 2014, 128
} 
dikarenakan tidak adanya iktikad baik dalam pelaksanaan jual beli hasil tangkapan walaupun sudah dilakukan dengan cara pelelangan ikan hasil tangkapan yang dilakukan oleh juru lelang yang dibentuk oleh Dinas Perikanan dalam hal ini dilaksanakan oleh Unit Pelayanan Teknis (UPT) Tempat Pelelangan Ikan (TPI) Mayangan Kota Probolinggo . Hal ini dikarenakan masyarakat sudah terbiasa dengan pelaksanaan jual beli ikan hasil tangkapan dilakukan secara tradisional atau hukum kebiasaan.

Seperti halnya tempat pelelangan ikan yang tak ubahnya sebagaimana pasar yang memiliki fungsi bertemunya penjual dan pembeli karena pasar merupakan suatu sistem yang mempunyai berbagai macam bentuk pengelolaan yang dalam konsepnya tempat berinteraksi antara penawaran dan permintaan, penjual dan konsumen yang mengarah kepada nilai lebih yang paling effesien. Karena keberadaan pasar, baik pasar moderen maupun pasar tradisional memiliki konsep yang berbeda dalam penataannya, walaupun penentuan harga ditentukan oleh mekanisme pasar yang didasarkan pada asumsi pada tawar menawar yang setara, pasar sebagai suatu institusi yang dikonotasikan sebagai suatu bangunan sosial dari masyarakat yang menawarkan lebih banyak variabel di luar permintaan dan penawaran sebagaimana halnya ideologi, tujuan politik, nilai-nilai agama, adat istiadat atau kebiasaan-kebiasaan dalam jual beli. ${ }^{7}$

Sehingga program yang dicanangkan oleh Dinas Perikanan untuk melakukan jual beli ikan dilakukan dengan sistem lelang tidak bisa dilaksanakan secara efektif, sehingga program yang dicanangkan oleh Pemerintah Kota Probolinggo tidak bisa dilanjutkan, hal ini dikarenakan :

a. Masyarakat yang terlibat dalam kegiatan jual beli ikan di Pelabuhan Perikanan Mayangan Kota Probolinggo sudah terbiasa dengan melakukan kegiatan jual beli ikan dengan sistem tradisional menurut hukum kebiasaan.

b. Keterbatasan keberadaan pegawai Unit Pelayanan Teknis (UPT) Tempat Pelelangan Ikan di Pelabuhan Perikanan Mayangan Kota Probolinggo dikarenakan purna tugas, sehingga tidak jalannya kegiatan pelelangan ikan yang dilaksanakan juru lelang. Hal ini menyebabkan masyarakat yang terlibat dalam

\footnotetext{
${ }^{7}$ Fahri Hamzah, Negara Pasar Dan Rakyat. Yayasan Faham Indonesia, Jakarta, 2011, 219.
} 
kegiatan jual beli hasil tangkapan di Pelabuhan Perikanan Mayangan Kota Probolinggo kembali dengan kebiasaan sebelumnya yaitu melaksanakan kegiatan jual beli ikan secara tradisional dan dilakukan secara langsung..

c. Kurangnya anggaran yang disediakan oleh Dinas Perikanan untuk membeli ikan hasil tangkapan di Pelabuhan Perikanan Mayangan Kota Probolinggo dari Pemilik Kapal/Juragan, sehingga mekanisme lelang tidak bisa terlaksana dengan sebaik-baiknya. Karena dalam melaksanakan lelang, UPT Tempat Pelelangan Ikan harus membeli ikan terlebih dahulu kepada juragan.

Di dalam hukum kontrak ada tiga unsur yang memuat tidak terpenuhinya kebebasan dalam berkontrak, sehingga iktikad baik tidak dapat dijalankan sebagaimana mestinya, yaitu :

a. Adanya unsur paksaan ( $d$ wang), unsur ini merupakan perbuatan yang dilakukan oleh satu pihak agar dalam perjanjian bisa dilaksanakan, karena pihak yang lain merasa terancam sehingga keinginan dari pihak lain tidak bebas.

b. Adanya unsur penipuan (bedrog), unsur ini mengandung arti bahwasannya satu pihak dalam membuat perjanjian dilakukan dengan segala daya dan upaya agar pihak lain menuruti kehendaknya, hal ini dilakukan dengan cara tipu muslihat dengan sengaja mengeluarkan kata-kata bohong dan memberikan pandangan yang salah sehingga mempengaruhi pihak yang lain tertarik untuk menuruti kehendaknya.

c. Adanya unsur kekeliruan ( $d$ waling), kekeliruan dilakukan oleh salah satu pihak salah dalam menjelaskan atau menerangkan objek yang diperjanjikan tanpa adanya kesengajaan yang dilakukan, ataupun tanpa adanya maksud untuk menipu baik dengan perbuatan maupun dengan kata-kata. Sehingga dalam perjanjian jual beli masing-masing pihak wajib mengecek barang yang diperdagangkan, hal ini dilakukan agar kekeliruan bisa terhindar dan barang yang diperjual belikan sudah diketahui jenis, wujud serta kualitasnya.

Sehingga inilah yang menyebabkan dalam pelaksanaan jual beli ikan hasil tangkapan di Kota Probolinggo memicu terjadinya konflik antara para pedagang karena berebut untuk mendapatkan objek yang akan diperjual belikan. 
Jatuh bangunnya institusi pasar dalam suatu negara merupakan jalan pembuka bagi kekuatan maupun kelemahan negara itu sendiri. ${ }^{8}$

\section{Upaya yang Dilakukan oleh Dinas Terkait Untuk Menghindari Konflik dalam}

\section{Praktek Jual Beli Ikan Hasil Tangkapan}

Menurut Adam Smith yang dikutip Bambang Sugiharto : Dalam konsep ekonomi pasar atau pasar bebas, intervensi negara justru sangat dibutuhkan untuk mengatasi masalah kesenjangan sosial sebagaimana pada konsep negara kesejahteraan dan penerapan good governance sebagaimana yang diatur pada Peraturan Pemerintah Nomor 101 Tahun 2000, dalam hal ini pemerintah bertugas :

a. Partisipasi semua elemen masyarakat dalam penyelenggaraan negara.

b. Penegakan aturan hukum dalam rangka menghindari tindakan kesewenangwenangan dan pemaksaan sepihak.

c. Transparan dan bertanggung jawab dalam setiap penyelenggaraan kegiatan.

d. Berkeadilan dalam rangka memberikan pelayanan kepada masyarakat untuk mencapai keadilan sosial. ${ }^{9}$

Sehingga campur tangan pemerintah sangat dibutuhkan karena merupakan dasar kebijakan politik perekonomian secara nasional dan hukum perekonomian di negara kita dan diperlukan sejauh itu menunjang kebebasan dan keadilan. Sedangkan pihak-pihak dalam pelaksanaan jual beli ikan hasil tangkapan di pelabuhan perikanan melalui pelelangan yang dilakukan oleh para pihak adalah nelayan dan pengepul ikan dengan menerapkan hukum kebiasaan. Adapun sifat perjanjian jual beli ikan hasil tangkapan yang dilakukan di pelabuhan perikanan Kota Probolinggo adalah perjanjian yang menimbulkan perikatan, maksudnya pihak-pihak yang terlibat, baik nelayan, pengepul dan pedagang memiliki hak dan kewajiban sebagaimana peraturan perundang-undangan yang mereka kepakati bersama. $^{10}$

\footnotetext{
${ }^{8}$ Fahri Hamzah, Negara Pasar Dan Rakyat. Yayasan Faham Indonesia, Jakarta, 2011, 241.

9 Adnan Quthny, Abu Yazid (2017) "Hukum dalam Perspektif Islam dan Kapitalisme", AsySyari'ah: Jurnal Hukum Islam , 3 (1), 79.

${ }^{10}$ Ahmad Muzakki. 2020. "Studi Terhadap Fatwa DSN MUI Nomor 75 Tahun 2009 Tentang Penjualan Lansung Berjenjang Syariah (MLM Syariah)”. Asy-Syari'ah: Jurnal Hukum Islam 6 (2), 117.
} 
Sedangkan peran pemerintah dalam hal ini adalah Pemerintah Kota Probolinggo, yang mana dalam pelaksanaan perjanjian jual beli ikan hasil tangkapan di Pelabuhan Perikanan Mayangan Kota Probolinggo sebagai leading sektornya adalah Unit Pelayanan Teknis Tempat Pelelangan Ikan (TPI) Pelabuhan Perikanan Mayangan Kota Probolinggo selaku pembina para pihak yang terlibat di tempat pelelangan ikan yaitu, Juragan/pemilik kapal, nelayan dan pedagang/pengepul. Sehingga apabila dilakukan pembinaan secara terus menerus pelaksanaan perdagangan ikan hasil tangkapan antara juragan, nelayan dan pedagang dapat terhindar konflik di antara mereka hal ini disebabkan mereka melaksanakan dan mematuhi azas-azas yang ada di dalam hukum kontrak/ perjanjian yaitu :

\section{a. Asas Kebebasan Berkontrak}

Azas ini terdapat pada Pasal 1338 Ayat (1) KUH Perdata yang menyatakan bahwa : Setiap perjanjian yang dibuat secara sah berlaku sebagai undang-undang bagi masing-masing pihak yang membuatnya.

Asas kebebasan berkontrak merupakan suatu asas yang memberikan kemerdekaan kepada semua pihak untuk membuat atau tidak membuat perjanjian, mengadakan perjanjian dengan siapapun, menentukan isi perjanjian/pelaksanaan dan persyaratannya, menentukan bentuknya perjanjian yaitu tertulis atau lisan. ${ }^{11}$

\section{b. Asas Iktikad Baik (Te Goeder Trouw)}

Pengaturan tentang asas iktikad baik terdapat di dalam Pasal 1338 Ayat (3) KUH Perdata yang menyatakan bahwa : Suatu perjanjian harus dilaksanakan dengan iktikad baik. Tujuan penerapan prinsip iktikad baik (good faith) dan prinsip kewajaran (fair dealing) dalam setiap praktek kegiatan bisnis dengan prinsip kejujuran (Cindawati, $2014: 1900{ }^{12}$

Ada dua jenis yang dimaksud dengan Azas Iktikad Baik, yaitu iktikad baik mutlak dan iktikad baik nisbi. Iktikad baik mutlak merupakan suatu penilaian kepada subjeknya ditujukan kepada keseimabangan dan akal waras, sedangkan iktikad baik nisbi pihak-pihak yang terlibat memperhatikan sikap dan perbuatan

\footnotetext{
${ }^{11}$ Subekti R dkk, Kitab Undang-Undang Hukum Perdata, PT. Pradnya Paramita, Jakarta, 2008, 76.

${ }^{12}$ Cindawati, Jurnal Ilmiah Mimbar Hukum, Volume 26 Nomor 2, Tahun 2014, 67
} 
yang dilakukan sehari-hari. ${ }^{13}$ Baik iktikad baik mutlak maupun iktikad baik nisbi dipergunakan oleh pihak-pihak yang terlibat untuk pedoman penilaian secara objektif seseorang sebelum membuat perjanjian. ${ }^{14}$

Pembinaan secara berkala dan berkesinambungan dilakukan oleh Dinas Perikanan Kota Probolinggo melalui Unit Pelayanan Teknis (UPT) Tempat Pelalangan Ikan (TPI) Mayangan Kota Probolinggo dengan cara membentuk kelompok kerukunan nelayan dn pedagang ikan Mayangan, agar terbentuk azas kekeluargaan dalam pelaksanaan kegiatan jual beli ikan hasil tangkapan di Pelabuhan Perikanan Mayangan, sehingga para pihak yang terlibat merasa seperti keluarga. Hal inilah yang membuat pelaksanaan jual beli ikan di Pelabuhan Perikanan Mayangan Kota Probolinggo tidak pernah terjadi konflik antar mereka yang terlibat, karena dilakukan dengan iktikad baik.

\section{KESIMPULAN}

Berdasarkan hasil penelitian dan analisis dengan melakukan tatap muka langsung yang berupa wawancara dengan nara sumber di lapangan, yaitu di lokasi objek penelitian, maka dapat disimpulkan bahwa dengan menerapkan Azas Iktikad Baik dalam jual beli ikan hasil tangkapan di Pelabuhan Perikanan Mayangan Kota Probolinggo yang dilakukan antara Pemilik Kapal/Juragan, Nelayan dan Pedagang dapat membangun kepercayaan untuk menghindari konflik di antara mereka. Meningkatkan peran pemerintah Kota Probolinggo dalam hal ini Dinas Pertanian Tanaman Pangan dan Perikanan Kota Probolinggo dalam hal pembinaan kepada para Juragan, nelayan dan pedagang untuk membangun kepercayaan antara mereka dapat terus terwujud melalui peranserta dan pembinaan yang dilakukan oleh Kepala Unit Pelayanan Teknis (UPT) Tempat Pelelangan Ikan di Pelabuhan Perikanan Mayangan Kota Probolinggo.

13 Arwadi. (2017). Studi Komparasi Tentang Batasan Khiyar Al-'Aib dalam Jual Beli Menurut Mazhab Syafi'i dan Hukum Perdata. Asy-Syari'ah: Jurnal Hukum Islam , 3 (1), 67.

${ }^{14}$ Ridwan Khairandi, Iktikad Baik Dalam Kebebasan Berkontrak, Pasca Sarjana Universitas Indonesia Press, Jakarta, 2004, 141. 


\section{DAFTAR PUSTAKA}

Adnan Quthny, Abu Yazid (2017) "Hukum dalam Perspektif Islam dan Kapitalisme”, AsySyari'ah: Jurnal Hukum Islam , 3 (1).

Ahmad Muzakki. 2020. "Studi Terhadap Fatwa DSN MUI Nomor 75 Tahun 2009 Tentang Penjualan Lansung Berjenjang Syariah (MLM Syariah)". Asy-Syari'ah: Jurnal Hukum Islam 6 (2).

Anjarsri, Pelaksanaan Azas Iktikad Baik Dalam Perjanjian Jual Beli Secara Online, Jurnal Ilmiah Privat Law, Volume 6 Nomor 1, Tahun 2018

Arwadi. (2017). Studi Komparasi Tentang Batasan Khiyar Al-'Aib dalam Jual Beli Menurut Mazhab Syafi'i dan Hukum Perdata. Asy-Syari'ah: Jurnal Hukum Islam , 3 (1).

Barnabas Dumas Manery, Jurnal Ilmiah Sasi, Volume 23 Nomor 2, Tahun 2017.

Cindawati, Jurnal Ilmiah Mimbar Hukum, Volume 26 Nomor 2, Tahun 2014.

Fuady, Munir, Hukum Kontrak (Dari Sudut Pandang Hukum Bisnis), PT. Citra Adiitya Bakti, Bandung, 1999.

H.S. Salim, Perkembangan Hukum Kontrak Innominat Di Indonesia, Sinar Grafika, Jakarta, 2003.

Hamzah, Fahri. Negara Pasar Dan Rakyat. Yayasan Faham Indonesia, Jakarta, 2011.

Herlien Budiono, Ajaran Umum Hukum Perjanjian dan Penerapannya di Bidang Kenotariatan, Citra Aditya, Bandung, 2010.

Idrus, Muhammad, Metode Penelitian Ilmu Soial, Erlangga, Jakarta, 2009

Khairandi, Ridwan, Iktikad Baik Dalam Kebebasan Berkontrak, Pasca Sarjana Universitas Indonesia Press, Jakarta, 2004.

Kitab Undang-Undang Hukum Perdata Buku III.

Kumorotomo, Wahyudi, Raja Grafindo Persada, Depok, 2015

Mahmud, Peter, Penelitiah Hukum, Prenada Media, Jakarta, 2014.

Mertokusumo, Sudikno, Mengenal Hukum Suatu Pengantar, Liberti, Yogyakarta, 2005.

Peraturan Pemerintah Nomor : 101 Tahun 2000 tentang Pemerintahan Yang Baik. 
Peraturan Presiden Nomor 112 Tahun 2007 tentang Perlindungan, Pemberdayaan Pasar Tradisional dan Penataan Pasar Modern.

Peraturan Wali Kota Probolinggo Nomor 9 Tahun 2011 tentang Perlindungan, Pemberdayaan dan Penataan Pasar Modern.

Priyono, Agus, Aspek Keadilan Dalam Kontrak Bisnis, Jurnal Ilmiah Law Reform, Volume 14 Nomor 1, Tahun 2018.

Prodjodikoro, Wirjono, Azas-Azas Hukum Perjanjian, Mandar Maju, Bandung, 2011

Purwahid Patrik, Henry Rizarrd Rumopa,Keabsahan Perjanjian, Fakultas Hukum UI, 2010.

Salim, Hukum Kontrak Teori \& Teknik Penyusunan Kontrak, Sinar Grafika, Jakarta, 2006.

Setiawan, Damang.web.id/2011/12/hukumpenelitian.htl

Simanjuntak, Ricardo, Teknik Perancangan Kontrak Bisnis, PT. Gramedia, Jakarta, 2011

Subekti R dkk, Kitab Undang-Undang Hukum Perdata, PT. Pradnya Paramita, Jakarta, 2008.

Subekti, Hukum Perjanjian, PT.Intermasa, Jakarta, 1979.

Sudarmaryanti, Good Governance dan Good Corporate Governance, Mandar Maju, Bandung, 2007.

Sugiyono, Memahami Penelitian Kualitatif, CV. Alfabeta, Bandung, 2014.

Suharto, Edi, Analisa Kebijakan Publik, Alfabeta, Bandung, 2010

Wawancara dengan Bapak H. Bambang Pedagang/Pengepul Ikan di Tempat Pelelangan Ikan Pelabuhan Perikanan Mayangan Kota Probolinggo.

Wawancara dengan Bapak H. Jupri Nelayan di Pelabuhan Pantai Mayangan Kota Probolinggo

Wawancara dengan Bapak H. Mohammad Syafi'i Juragan Kapal.di Mayangan Kota Probolinggo.

Wawancara dengan Ibu Renny Noviani Annisa Kepala UPT-TPI Mayangan Kota Probolinggo. 